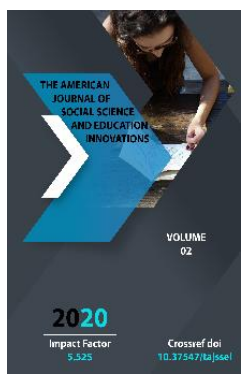

Copyright: Original content from this work may be used under the terms of the creative commons attributes 4.0 licence.

\section{Representation Of Applying The Method Of Oral History In Russian History}

Mukhammadjon Samatovich Azimbaev

Junior Researcher, The Institute Of History Of The Academy Of Sciences Of The Republic Of Uzbekistan

\section{Umida Samatovna Usmanova}

Researcher, Tashkent State Agrarian University, Uzbekistan

\title{
ABSTRACT
}

This article gives full information on representation of applying the method of oral history in Russian history. The practical application of this method in historical researches was discussed in detail by Russian historians in scientific seminars in the last years of the Soviet Union. Therefore it is logical to include some scientific works created during the Soviet era in categorizing the researches on oral history in Russia. So, our aim is to discuss the method of oral history in Russian researches.

\section{KEYWORDS}

Russian history, Soviet era, method, respondents, conversation.

\section{INTRODUCTION}

The works of Russian researchers on oral history are noteworthy for their wide-ranging and controversial nature. The practical application of this method in historical researches was discussed in detail by Russian historians in scientific seminars in the last years of the Soviet Union. Therefore it is logical to include some scientific works created during the Soviet era in categorizing the researches on oral history in Russia.
One of the works on oral history was conducted by V.D. Duvaking who recorded and interviewed more than 800 respondents such as writers, scientists, poets, painters, artists, and directors in the process of developing phono-documents on Russian culture and history of science in twentieth century[1]. V.D. Duvakin's interview materials are categorized into three groups: 1) monographs; 2) extended conversations; 3) multi-topic conversations. 
Although this study is an important source in the study of the history of Russian culture and science in the twentieth century, some of the methods of the oral history were used during interviews conducted during the study. In particular, no technical means were used during the interview and, the conversations were not transcribed. Nevertheless, these scientific studies somehow reflected the new method that was developed extensively in the United States and Western Europe. This, in turn led to an increase of the interest of Russian researchers in this method. It was started in the article of archival experts N.P. Kuznetsova and V.M. Surinov who presented brief information about the implementation of programs on oral history abroad[2]. It provides information about the interviews with representatives of different sciences and the collections in which the memoirs of scientists and artists were gathered during the research conducted in Australia. The authors of the article tried to show the practical results of the new method to the general scientific community on the basis of their brief references applying for foreign experience.

According to the characteristics, a coauthored work "Reppresirovannaya Nauka (Repressed Science)" prepared by a group of scholars under M.G. Yaroshevsky could be presented among the studies in which the oral history method was used in the early 1990s[3]. It is illustrated dramatic events in Soviet science in the 1930 s and 1960 s by the testimonies of a number of prominent Russian scientists.

Methodological issues of oral history began to appear in scientific works of Soviet researchers in the late 1980s. In particular, such researchers as T.N. Musatova, V.M. Vinogradov, M.Ya. Rozhansky analyzed the method on historical issues in interviews, the significance of materials on oral history as a source, and of critique of source studies, as well as the issue of long-term preservation of oral sources in their researches[4].
Accordingly these studies highlighted important aspects of the oral history method.

The first PhD dissertation which reflects the theoretical issues of oral history in Russia was written by D.N. Khubova. The researcher attempted to illustrate a number of theoretical and practical aspects of the method of oral history in her research work and in monograph based on it. In particular[5], she focuses on the technical problems of documenting oral sources, making priority in selection of respondents, transcription of oral documents and their use in scientific circulation. Besides, the author discusses the origin of the term oral history and the development of this method using examples of United States, Great Britain, and France. The significance of the investigation of this researcher is that she gives her specific proposals to organize the archives of oral sources. However, since this work has been one of the early researches of Russian specialists in oral history, it doesn't avoid the shortcomings. For instance, the researcher failed to disclose the essence of the modern historiographical concept of oral history, which she wanted to do in the part of introduction of the work. In addition, she stated that the method of oral history in the United States was first introduced by $A$. Nevins in 1948[6]. However, according to sources, the first work that embodies some features of the oral history method in the United States was written by a journalist and a historian Studs Terckle from Chicago in the 1930s, where the author interviewed the eyewitnesses and victims of slavery in their young age in the south of the USA in the 1930s. Later, S. Terckle's research led to data collection and start of studies based on the oral history method in the United States.

Another PhD dissertation on oral history was defended by a researcher M.V. Mokrova. The work illustrates the analysis of the term "oral history", the influence of the development of technical means on oral history, 
interdisciplinary relationship, and methods of conducting research in oral history[7]. However, the study of the research shows that the author does not sufficiently disclose data collected on the basis of the oral history method used in this dissertation by analyzing source studies, but avoiding the main purpose attempting to answer the question of whether a respondent or a researcher is the author of the document relating to the oral history.

One of the scientific research conducted in Russia is the work of M.V. Loskutova: "Reading book of Oral History"[8] which was published in 2003. The theoretical and practical issues of the method of oral history were presented on the basis of scientific articles and researches of foreign experts. This work is valuable due to clear approaches on the aims and objectives of oral history by researchers such as $M$. Frisch, A. Portelli, Y. Vansin, P. Thompson and etc. who had rich practice in the methods of "oral history".

It should be noted that reading of this book explains the general aspects of oral history. However, it does not present its methodic aspects such as the organization of the interview, the use of technical means during the interview, as well as organization and storage of archives. Furthermore, the book does not entirely disclose the researchers conducted in the field of oral history in the United States and Western Europe. The author of the book, rich on data, did not mention valuable works like: Battimer's research "Put $v$ geografiyu (A road to Geography)"[9] who was the first recorded the interviews on video tape, V. Mossa's work "Oral History: An Appreciation"[10] which is dedicated to the analysis of oral history sources.

Professor T.K. Scheglova has been using the method of oral history in practice for a long time and has carried out fundamental research work on it. Scheglova's textbook covers extensive theoretical and practical aspects of the oral history method, as well as thematic questions and questionnaires are presented to learners based on the oral history method. The author of this textbook has perfected the work by deeply analyzing the scientific researches in which the theoretical aspects had been illustrated. In addition, she studied the situation of agriculture and peasantry in Altai territory in the twentieth century applying for the method, and published the derived results in her monograph[11]. This, in turn, indicates that the author had conducted a thorough theoretical and practical research of the oral history method before publishing the textbook.

Russian historians are very interested in the field of oral history. What is more, scientific conferences have been held for several years on the importance of this method in terms of representation historical reality. The speeches and collections of published scientific articles at these conferences are considered as important sources in the study of oral history method[12]. The theoretical and practical aspects of the method are reflected in the published materials of the seminar held by Barnaul State Pedagogical University and its partner organizations[13].

In that scientific collection, M.V. Loskutova's article entitled "Ustnaya istoriya v Velikobritanii i SSHA v 1990-x - nachale 2000-x gg.: obzor osnovnykh tendentsiy $i$ isledovaniy, posvyashchennykh istorii Rossii i SSSR (Oral History in Great Britain and the USA in 1990ies - beginning 2000ies: the reflection of main tendencies and researches devoted to Russia and the USSR)" has a special value[14]. In the article the author examines the dynamics of changes of the main trends of the oral history conducted in the United States and the United Kingdom.

According to the author, the content, theoretical and conceptual foundations and 
trends of the research linking with oral history have changed in context of socio-economic changes. While initially the research composed biographies of political elites, later focused on the lives of workers. As a result, there appeared a tendency to study history from below.

D.N. Khubova in her article "Ustnyj arkhiv: tekhnologija dokumentirovanija $v$ ustnoj istorii (Oral history: the technology of documentation in oral history)", focused on the problem of archiving the materials collected on the basis of oral history[15]. According to her, despite effective involvement researches in oral history in Western Europe, the issue of documenting and archiving oral sources has not yet been developed. This, in turn, causes difficulties for researchers to place their materials in archives. The author proposed to develop a unique standard for archiving oral sources carrying out international scientific-practical seminars.

\section{CONCLUSION}

The method of oral history has a specific role in Russian historiography. There have been carried out a number of works applying this method in practice. These researches, concern the history of cities and villages as the object of study.

The studies metioned above as examples on the theoretical and practical aspects of the method of oral history conducted by Russian researchers represent the development of Russian research school in this new field of study.

\section{REFERENCES}

1. Zapiska V.D. Duvakina «O moej rabote na kafedre Nauchnoj informacii MGU» I Predislovie: Tejder V.F. II Arkheograficheskij ezhegodnik za
1989 god. - M.: Nauka, 1990. - Pp. 306-313.

2. Kuznecova N.P., Surinov V.M. «Ustnaja istorija» v praktike raboty zarubezhnyh arkhivov i nauchnykh uchrezhdenij // Sovetskie arkhivy. 1980. \# 1. - Pp. 7376.

3. Repressirovannaja nauka / Pod obshh. red. M.G. Jaroshevskogo. - L.: Nauka, 1991. - P. 559.

4. Musatova T.N., Kuz"michev N.A., Seregin A.V. «Ustnaja istorija» kak metod aktivnogo komplektovanija // Problemy khranenija i obespechenija sokhrannosti arkhivnykh dokumentov. Sbornik nauchnykh trudov. - M.: NICTD SSSR, 1985. - Pp. 14-21; Vinogradov V.M., Rjabov A.V. «Ustnaja» istorija i komplektovanie gosudarstvennykh arkhivov (Postanovka problemy) // Aktual'nye problemy sovetskogo arkhivovedenija. Mezhvuzovskij sbornik. - M.: MGIAI, 1986. - Pp. 6-16; Rozhanskij M.Ja. «Ustnaja istorija» - filosofija pamjati // Obshhestvennye nauki. 1990. \# 6. - P.. 141-150.

5. Khubova D.N. Ustnaja istorija i arkhivy: zarubezhnye koncepcii i opyt.: Avtoref. diss. ... kand. ist. nauk. - M., 1992. - P. 19; «Ustnaja istorija» $i$ istochnikovedenie: istoricheskoe interv'ju, iniciativnoe dokumentirovanie ili «fabrikacija» istoricheskogo istochnika? // Istochnikovedenie XX stoletija. Tez. dokl. i soobshh. nauch. konf. - M.: RGGU IAI, 1993. - Pp. 21-25; «Ustnaja istorija» $\mathrm{i}$ istochnikovedenie: «V poiskakh utrachennogo vremeni» // Mir istochnikovedenija. Sbornik $v$ chest' Sigurda Ottovicha Shmidta. M.: RGGU; Penza, 1994. - Pp. 57-63; Ustnaja istorija. «Verba Volant?». Metodicheskoe posobie. - M.: RGGU, 1997. - P. 52.

6. Adilov, J. K. U., Tursunmetov, A. A., Samatovich, M., Azimbayev, O. G. P., \& 
Tukhtayeva, M. S. (2020). ESSAYS ON HISTORIOGRAPHY AND SOURCE STUDIES ON THE HISTORY OF STATEHOOD IN UZBEKISTAN. Journal of Critical Reviews, 7(9), 2020..

7. Mokrova M.V. Ustnaja istorija nauki: ot istoriograficheskikh tradicij $\mathrm{k}$ kompleksnomu istochnikovedeniju.: Diss. ... kand. ist. nauk. - M., 2004. - P. 253.

8. Khrestomatija po ustnoj istorii. - SPb.: Izd-vo Evrop. un-ta $v$ SanktPeterburge, 2003. - P. 396.

9. Battimer A. Put' v geografiju / Per. s ang.- M.: Progress, 1990. - P. 440.

10. Moss W. Oral History: An Appreciation // Oral History: an interdisciplinary anthology, 1996. - Pp. 107-120.

11. Scheglova T.K. Ustnaja istorija (Uchebnoe posobie). - Barnaul, 2010. - S. 364; Derevnja i krest'janstvo Altajskogo kraja v XX veke.- Barnaul, 2008. - P. 528.

12. Metodologicheskie problemy ustnoj istorii // Istochnikovedenie otechestvennoj istorii. Sb. statej. M., 1989. Pp. 3-32; Korneev V.E. Ustnaja istorija: 20-e gody // Istochnikovedenie XX stoletija: Tezisy dokladov i soobshhenij nauchnoj konferencii. Moskva, 28-30 janvarja 1993 g. - M.: RGGU IAI, 1993. - Pp. 75-77; Ustnaja istorija nauki i problemy arheografii audiovizual'nyh istochnikov // Institut istorii estestvoznanija i tekhniki im. S.I.Vavilova. Godichnaja nauchnaja konferencija, 2004. - M.: Dipol', 2004. - Pp. 282-287.

13. Ustnaja istorija (Oral History): teorija i praktika // Materialy Vserossijskogo nauchnogo seminara. Barnaul, 25-26 sentjabrja 2006 g. - P. 374.

14. Loskutova M.V. Ustnaja istorija v Velikobritanii i SShA v 1990-kh nachale 2000-kh gg.: obzor osnovnykh tendencij i isledovanij, posvjashhennykh istorii Rossii i SSSR // Ustnaja istorija (Oral History): teorija i praktika // Materialy Vserossijskogo nauchnogo seminara. Barnaul, 25-26 sentjabrja 2006 g. - P. 176-196.

15. Khubova D.N. Ustnyj arkhiv: tekhnologija dokumentirovanija $\mathrm{v}$ ustnoj istorii // Ustnaja istorija (Oral History): teorija i praktika // Materialy Vserossijskogo nauchnogo seminara. Barnaul, 25-26 sentjabrja 2006 g. - Pp. 197-201.

16. Nazarov, A. Y. (2020). Scientific societies in the Turkestan governorate-general as an instrument of colonial statehood (archival source study). Journal of Critical Reviews, 7(7), 1068-1073.

17. Adilov, J. K. U., Tursunmetov, A. A., Samatovich, M., Azimbayev, O. G. P., \& Tukhtayeva, M. S. (2020). ESSAYS ON HISTORIOGRAPHY AND SOURCE STUDIES ON THE HISTORY OF STATEHOOD IN UZBEKISTAN. Journal of Critical Reviews, 7(9), 2020.

18. Azimbaev, M. (2020). Public policy of the governor-general of turkestan towards traditional muslim education (based on the literature of colonial period). ACADEMICIA: An International Multidisciplinary Research Journal, 10(4), 793-799.

19. Азимбаев, М. С. (2014). Традиционное образование в Туркестанском крае по архивным материалам Центрального государственного архива Республики Узбекистан. Документ. Архив. История. Современность.Екатеринбург, 2014, 270-274. 